Original Research Article

\title{
A prospective open label study of efficacy and tolerability of topical tacrolimus in Vitiligo
}

\author{
A. Suguna Bai ${ }^{1}$, G. Sujatha², N. Preetha ${ }^{2 *}$
}

${ }^{1}$ Department of Pharmacology, Govt Tiruvannamalai Medical College, Tiruvannamalai, Tamil Nadu, India

${ }^{2}$ Department Pharmacology, Govt Mohan Kumaramangalam Medical College, Salem, Tamil Nadu, India

\section{Received: 05 April 2017} Accepted: 01 May 2017

*Correspondence to:

Dr. N. Preetha,

Email: preetha.nandabalan@ gmail.com

Copyright: (C) the author(s), publisher and licensee Medip Academy. This is an openaccess article distributed under the terms of the Creative Commons Attribution NonCommercial License, which permits unrestricted noncommercial use, distribution, and reproduction in any medium, provided the original work is properly cited.

\begin{abstract}
Background: Vitiligo is a cosmetically and psychologically devastating clinical conundrum with various hypotheses of etiology inclusive of an immunological one too. Long term clinical visits, various adverse effects and cost of therapy are the major limitations of current treatment of vitiligo. Topical Tacrolimus which has been tried and found useful in various skin conditions with immunological basis was evaluated for its efficacy and tolerability compared with the available standard treatment of Topical Betamethasone.

Methods: The study was done in the outpatient unit of Department of Dermatology, Stanley medical college, for duration of six months. Newly diagnosed vitiligo patients attending the outpatient clinic were taken for the study. A randomised, open labelled, comparative study of efficacy and tolerability of Topical Tacrolimus in vitiligo was done.

Results: Early onset of repigmentation, higher mean repigmentation with no significant side effects systemically or topically were observed in the study group compared to the control group.

Conclusions: This study shows that Topical Tacrolimus produces rapid and significant repigmentation with less significant side effects in vitiligo. Topical Tacrolimus is more efficacious and better tolerated than available standard Topical Betamethasone.
\end{abstract}

Keywords: Betamethasone, Tacrolimus, Vitiligo

\section{INTRODUCTION}

Vitiligo is a chronic skin condition characterized by areas of achromatic lesions affecting epidermis and perisebaceous follicles. ${ }^{1}$ It affects $1 \%$ of the general population.

It is a common, idiopathic, acquired/inherited progressive disorder with loss of normal melanin pigments and functioning melanocytes from otherwise healthy looking skin. In addition to the morbidity it affects patient psychologically and his relationship with the society. It has a major impact on the quality of the life of the patient. Even now in this modern era myths and stigmata concerning vitiligo persists. Hence vitiligo affects the physical, mental and social health of the affected person. There is so many theories about the pathogenesis of vitiligo. Topical-Corticosteroids, PUVA, Eximer laser, Systemic-Phototherapy with PUVA, UV-B microphototherapy, combination of calcipotriene and narrow band UV-B or PUVA, systemic steroids and surgical management like punch grafts, minigrafts, suction blister epidermal grafts, autologus melanocyte grafts and micropigmentation etc. are the treatments available at present but none of these produce a complete remission. $^{2}$ 
Further compliance for regular long term visits for PUVA, narrow band UV-B therapy, long term risk of photoageing and carcinogenesis with phototherapy, side effects of immunosuppressive therapy and cost of therapy are the limitations of these treatment methods.

This initiate the drive for exploring other safer, more efficacious, cost effective alternative treatment which is easy to administer, by the patient himself at his home and without affecting his day to day life style.

A Topical formulation will have more impact on the patient's morale and at the same time reduce the unwanted side effects.

Tacrolimus a macrolide which inhibits Interlukin-2 expression in the T-cells is a prototype of a class of immunosuppressive agents. It has been tried and found useful in the treatment of various skin conditions. ${ }^{3}$ So in this study topical Tacrolimus is evaluated for its efficacy and tolerability compared with topical Betamethasone which is the available standard drug in this hospital.

\section{METHODS}

The study was carried out in the outpatient Unit of Department of Dermatology, Government Stanley Medical College for a period of six months. Newly diagnosed patients with vitiligo were enrolled for the study.

\section{Study design}

It is a Prospective, Randomised, Open labelled, comparative study with 60 patients (30 patients in GroupI and 30 patients in Group-II).

\section{Inclusion criteria}

1. Age: $18-45$ years

2. Both sex.

3. Patients with clinically confirmed diagnosis

4. Lesions less than $2 \mathrm{cms}$.

5. Lesions less than 6 month's duration.

6. Lesions in the face, neck and forearm.

\section{Exclusion criteria}

1. Patients with extensive lesions

2. Pregnant and lactating mothers

3. Patients with diagnosis of diabetes mellitus and hypertension

4. Patients with known history of immunodeficiency or other known autoimmune disease.

5. Patients with renal disease.

6. Patients who were not willing to give informed consent to the study.

\section{Enrolment}

The study was conducted after obtaining approval from the Institutional Ethical Committee. New Patients who attended the Outpatient clinic of Department of Dermatology in Government Stanley Medical College with a diagnosis of vitiligo were explained about the study purpose and procedures. Written Informed consent in their own language was obtained from those who were willing to participate in the study.

After thorough general and systemic examination, blood was drawn for haematological and biochemical tests for liver and renal function. The base line demographic characters were recorded. A detailed clinical examination was done and percentage of body surface area involved was assessed using RULE OF NINE. After obtaining written consent punch biopsy of skin was done under strict aseptic precautions using local anesthesia. Histopathological examination was done and opinion obtained from institutional pathologist.

A total number of 60 patients were enrolled for the study. They were randomized and allotted to two groups with 30 in each group.

Group-I (control group) applying 1\% Betamethasone and Group-II (Study Group) applying $0.1 \%$ Tacrolimus ointment. All the patients were instructed to apply $1 / 3^{\text {rd }}$ of a fingertip unit of ointment twice daily for a continuous period of eight weeks. Patients were instructed to report any adverse effects immediately. Compliance was verified by instructing the patients to return the used empty ointment tubes to the investigator. Also, they were asked to maintain a diary to note down any events and to bring the diary at each visit.

\section{Evaluation and follow up}

The patients were asked to come to the clinic at the end of every two weeks after application of the drugs. They were evaluated for the repigmentation using RULE of NINE by the Dermatologist in the institution. The haematological and biochemical parameters were reassessed at the end of 8 weeks to evaluate any undesirable changes in the functions of vital organs, even though topical application of Tacrolimus has not found to produce any systemic toxicity in the previous studies done till date. Punch biopsy of the lesion after the treatment was taken, Histopathological examination done and institutional pathologist opinion was obtained. After 8 weeks of treatment the patients were asked to come for follow up once in a month for 6 months.

\section{Data analysis}

The data thus obtained were analysed using appropriate statistical methods as per the requirement. 


\section{RESULTS}

A prospective open labelled comparative study was conducted to find out the efficacy and tolerability of Topical Tacrolimus over Topical Betamethasone in vitiligo patients in a medical college in south India.

The mean age distribution of the two groups was analysed statically. The mean age group in control group (28.07) and test group (29.73) showed no significant difference $(\mathrm{p}=0.48)$ (Figure 1).

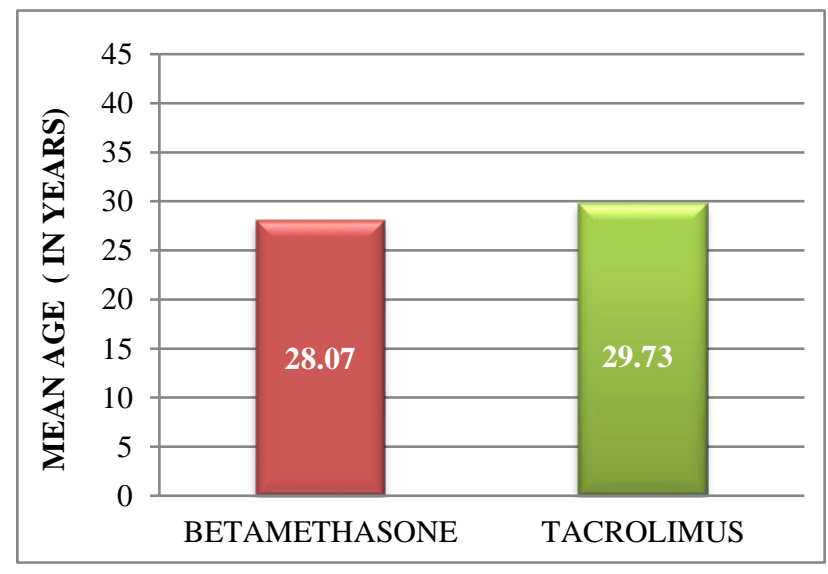

Figure 1: Comparison of mean age.

18 males and 12 females were enrolled in group I whereas 15 males and 15 females were in group II. Therefore, no significant difference $(p=0.44)$ in sex distribution between the two groups.

There was no significant difference between mean duration of lesion in both groups (Figure 2).

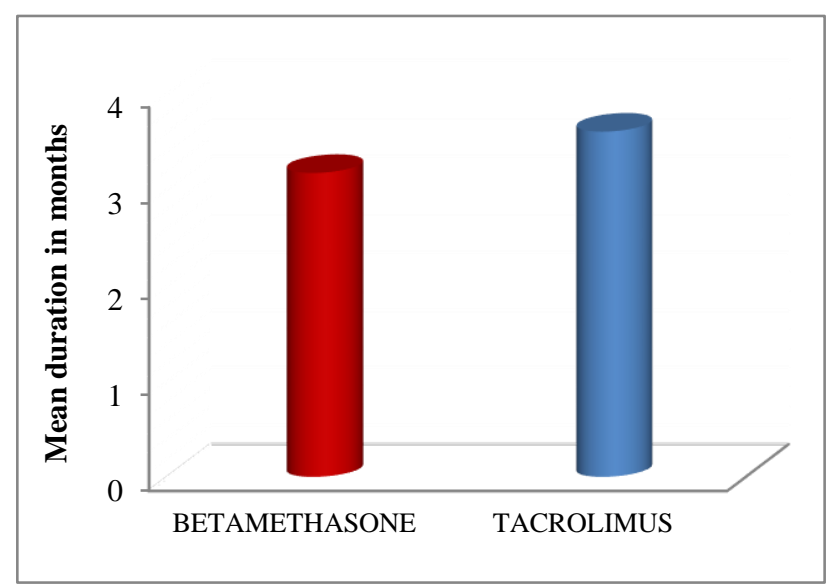

Figure 2: Duration of lesion.

There was no significant difference $(\mathrm{p}=0.82)$ in mean site of lesion (Figure 3). There was no significant difference in the mean size of lesion in both groups (Figure 4). The percentage of repigmentation in both groups was analysed. There was no significant difference between the groups at baseline (Figure 5).

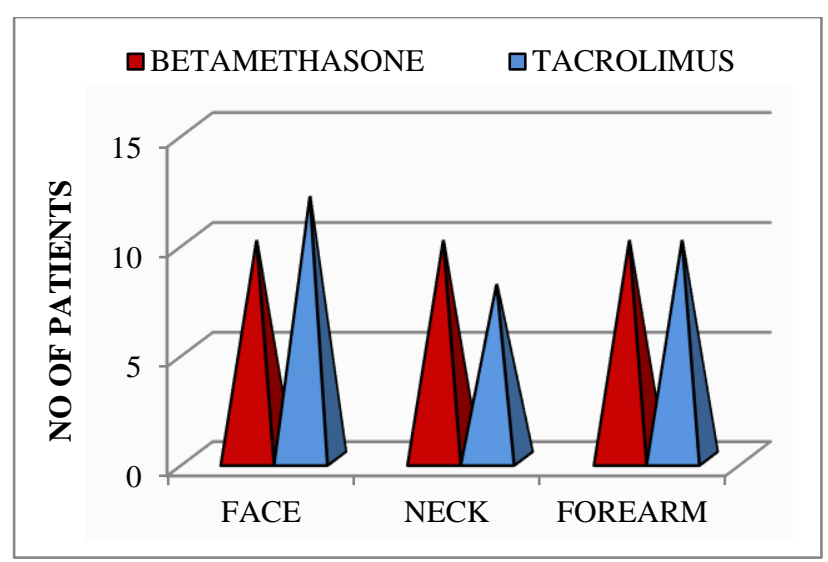

Figure 3: Site of the lesion.

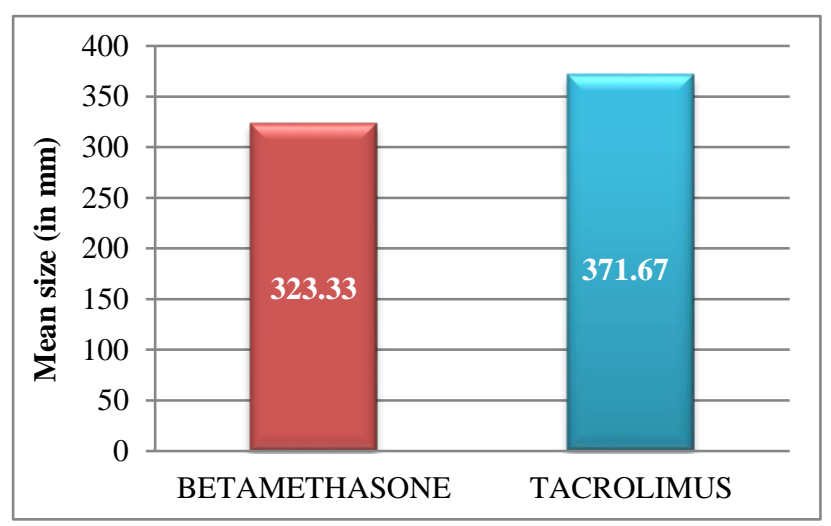

Figure 4: Comparison of mean size (in mm).

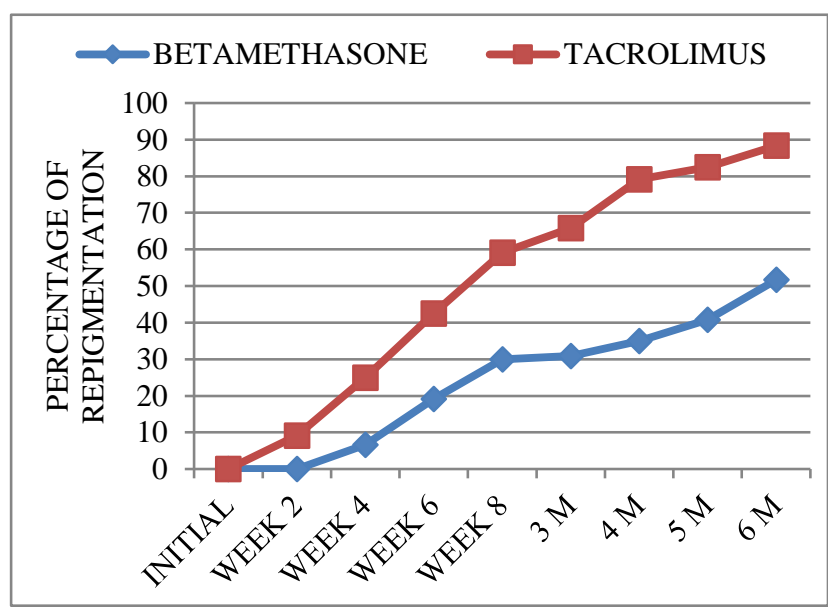

Figure 5: Comparison of percentage of mean pigmentation in both groups.

The Percentage of repigmentation in both groups were statistically analysed using student independent ' $t$ ' test and $\mathrm{p}$ value was significant. From the second week, onwards there was significant repigmentation in the study group i.e. Group - II (Tacrolimus) over Group I (Betamethasone) throughout the period (Table 1). The comparison of repigmentation in face showed significant difference $(\mathrm{P}=0.001)$ between two groups (Table 2$)$. 
Table 1: Percentage of repigmentation in both groups.

\begin{tabular}{|llllll|}
\hline Duration & $\begin{array}{l}\text { Group } \\
\text { Betamethasone }\end{array}$ & Tacrolimus & & $\begin{array}{l}\text { Student independent } \mathbf{t} \text { test } \\
\mathbf{p}=\mathbf{1 . 0 0} \text { not significant }\end{array}$ \\
& Mean & SD & Mean & SD & $\begin{array}{l}\mathbf{p}=\mathbf{0 . 0 0 0 1} \text { significant } \\
\text { Initial }\end{array}$ \\
\hline Week 2 & 0.00 & 0.00 & 0.00 & 0.00 & $\mathrm{p}=0.0001$ significant \\
\hline Week 4 & 0.00 & 0.00 & 9.17 & 12.25 & $\mathrm{p}=0.0001$ significant \\
\hline Week 6 & 6.67 & 11.24 & 25 & 16.08 & $\mathrm{p}=0.0001$ significant \\
\hline Week 8 & 19.17 & 16.97 & 42.5 & 20.92 & $\mathrm{p}=0.0001$ significant \\
\hline 3 M & 30.00 & 21.17 & 59.17 & 24.99 & $\mathrm{p}=0.0001$ significant \\
\hline 4 M & 30.83 & 21.46 & 65.83 & 27.45 & $\mathrm{p}=0.0001$ significant \\
\hline 5 M & 35.00 & 24.21 & 79.17 & 26.33 & $\mathrm{p}=0.0001$ significant \\
\hline 6 M & 40.83 & 26.65 & 82.5 & 26.38 & $\mathrm{p}=0.0001$ significant \\
\hline & 51.67 & 31.44 & 88.33 & 26.04 & $\mathrm{p}=0.0001$ significant \\
\hline
\end{tabular}

Table 2: Comparison of percentage of repigmentation in face.

\begin{tabular}{|lllllllllll|} 
Group & $\begin{array}{l}\text { Base } \\
\text { line }\end{array}$ & $\begin{array}{l}\mathbf{2} \\
\text { wks }\end{array}$ & $\begin{array}{l}\mathbf{4} \\
\text { wks }\end{array}$ & $\begin{array}{l}\mathbf{6} \\
\text { wks }\end{array}$ & $\begin{array}{l}\mathbf{8} \\
\text { wks }\end{array}$ & $\begin{array}{l}\mathbf{3}^{\text {rd }} \\
\text { month }\end{array}$ & $\begin{array}{l}4^{\text {th }} \\
\text { month }\end{array}$ & $\begin{array}{l}\mathbf{5}^{\text {th }} \\
\text { month }\end{array}$ & $\begin{array}{l}\mathbf{6}^{\text {th }} \\
\text { month }\end{array}$ & $\begin{array}{l}\text { Two way } \\
\text { repeated } \\
\text { Anova F test }\end{array}$ \\
\hline Betamethasone & 0 & 0 & 15 & 30 & 45 & 45 & 50 & 57.5 & 80 & $\begin{array}{l}\text { P= } 0.001 \\
\text { Tacrolimus }\end{array}$ \\
\hline & 12.5 & 25 & 45.8 & 72.9 & 79.1 & 89.5 & 93.75 & 95.8 & significant \\
\hline
\end{tabular}

Table 3: Comparison of percentage of repigmentation in neck.

\begin{tabular}{|lllllllllll} 
Group & $\begin{array}{l}\text { Base } \\
\text { line }\end{array}$ & $\begin{array}{l}\mathbf{2} \\
\text { wks }\end{array}$ & $\begin{array}{l}\mathbf{4} \\
\text { wks }\end{array}$ & $\begin{array}{l}\mathbf{6} \\
\text { wks }\end{array}$ & $\begin{array}{l}\mathbf{8} \\
\text { wks }\end{array}$ & $\begin{array}{l}\mathbf{3}^{\text {rd }} \\
\text { month }\end{array}$ & $\begin{array}{l}\mathbf{4}^{\text {th }} \\
\text { month }\end{array}$ & $\begin{array}{l}\mathbf{5}^{\text {th }} \\
\text { month }\end{array}$ & $\begin{array}{l}\mathbf{6}^{\text {th }} \\
\text { month }\end{array}$ & $\begin{array}{l}\text { Two way } \\
\text { repeated } \\
\text { Anova F test }\end{array}$ \\
\hline Betamethasone & 0 & 2.5 & 7.5 & 15 & 27.5 & 27.5 & 32.5 & 35 & 50 & $\begin{array}{l}\text { P=0.001 } \\
\text { Tacrolimus }\end{array}$ \\
\hline & 0 & 3 & 25 & 43.75 & 59.3 & 59.3 & 75 & 75.0 & 87.5 & significant \\
\hline
\end{tabular}

Table 4: Comparison of percentage of repigmentation in forearm.

\begin{tabular}{|c|c|c|c|c|c|c|c|c|c|c|}
\hline Group & $\begin{array}{l}\text { Base } \\
\text { line }\end{array}$ & $\begin{array}{l}2 \\
\text { wks }\end{array}$ & $\begin{array}{l}4 \\
\text { wks }\end{array}$ & $\begin{array}{l}6 \\
\text { wks }\end{array}$ & $\begin{array}{l}8 \\
\text { wks }\end{array}$ & $\begin{array}{l}3^{\text {rd }} \\
\text { month }\end{array}$ & $\begin{array}{l}4^{\text {th }} \\
\text { month }\end{array}$ & $\begin{array}{l}5^{\text {th }} \\
\text { month }\end{array}$ & $\begin{array}{l}6^{\text {th }} \\
\text { month }\end{array}$ & $\begin{array}{l}\text { Two way } \\
\text { Repeated } \\
\text { Anova F test }\end{array}$ \\
\hline Betamethasone & 0 & 0 & 2.5 & 15.0 & 17.5 & 20.0 & 22.5 & 30.0 & 35.0 & \multirow{2}{*}{$\begin{array}{l}\mathrm{P}=0.001 \\
\text { significant }\end{array}$} \\
\hline Tacrolimus & 0 & 15 & 25 & 32.5 & 47.5 & 57.5 & 70.0 & 75.0 & 80.0 & \\
\hline
\end{tabular}

Table 5: Final achievement of repigmentation of both groups.

\begin{tabular}{|lllllllllll|}
\hline & After 8 weeks & \multicolumn{1}{c|}{ After $\mathbf{6}$ months } \\
Study group & $\mathbf{0 \%}$ & $\mathbf{2 5 \%}$ & $\mathbf{5 0 \%}$ & $\mathbf{7 5 \%}$ & $\mathbf{1 0 0 \%}$ & $\mathbf{0 \%}$ & $\mathbf{2 5 \%}$ & $\mathbf{5 0 \%}$ & $\mathbf{7 5 \%}$ & $\mathbf{1 0 0 \%}$ \\
\hline Betamethasone & 5 & 17 & 5 & 3 & 0 & 4 & 5 & 11 & 5 & 5 \\
\hline Tacrolimus & 2 & 2 & 10 & 13 & 3 & 1 & 1 & 2 & 3 & 23 \\
\hline Chi square test & $\mathrm{X}^{2}=23.7 \mathrm{p}=0.001$ Significant & & $\mathrm{X}^{2}=18.5 \mathrm{p}=0.001$ Significant \\
\hline
\end{tabular}

Similarly, repigmentation in the neck showed a significant difference $(\mathrm{P}=0.001)$ between study group and control group (Table 3 ). Also, the repigmentation in the forearm was statistically significant $(\mathrm{P}=0.001)$ when compared between two groups (Table 4). The final achievement of repigmentation of both groups was analysed using chi square test. There is significant repigmentation in study group (Tacrolimus) over the control group (Betamethasone) both at the end of 8 weeks and after 6 months (Table 5).
The haematological and biochemical parameters were analysed statistically for both groups before and after the study (Table 6).

There were no significant changes in the parameters. Comparing the occurrence of adverse effects in the Tacrolimus group only two patients complained of transient burning sensation on application of the drug during the first week of treatment, which had subsided spontaneously. In the Betamethasone group three patients 
had shown thinning of skin at the site of application of the drug after the $6^{\text {th }}$ week. All the patients were followed up for a period of 6 months. No systemic side effects observed. None of the patients showed relapse.

Table 6: Comparison of hematological and biochemical parameters between groups.

\begin{tabular}{|c|c|c|c|c|c|c|c|c|c|c|}
\hline \multirow{3}{*}{ Parameters } & \multicolumn{5}{|c|}{ Tacrolimus } & \multicolumn{5}{|c|}{ Betamethasone } \\
\hline & \multicolumn{2}{|l|}{ Before } & \multicolumn{2}{|l|}{ After } & \multirow{2}{*}{$\begin{array}{l}\text { Student } \\
\text { paired } \\
\text { t test }\end{array}$} & \multicolumn{2}{|l|}{ Before } & \multicolumn{2}{|l|}{ After } & \multirow{2}{*}{$\begin{array}{l}\text { Student } \\
\text { paired t } \\
\text { test }\end{array}$} \\
\hline & Mean & SD & Mean & SD & & Mean & SD & Mean & SD & \\
\hline Haemoglobin & 10.793 & 0.9505 & 10.953 & 0.706 & $\mathrm{p}=0.07$ & 10.821 & 0.7678 & 10.848 & 0.6016 & $\mathrm{p}=0.77$ \\
\hline Total count & 8153.33 & 766.42 & 8123.33 & 627.905 & $p=0.63$ & 7463.33 & 502.74 & 7560 & 589.915 & $\mathrm{p}=0.42$ \\
\hline Polymorphs & 66.17 & 3.677 & 65.6 & 3.328 & $\mathrm{p}=0.41$ & 65.9 & 2.881 & 65.3 & 3.271 & $p=0.46$ \\
\hline Lymphocytes & 30 & 3.464 & 30 & 3.464 & $\mathrm{p}=0.61$ & 29.97 & 3.045 & 30.3 & 3.395 & $p=0.69$ \\
\hline Eosinophils & 3.83 & 1.053 & 4 & 1.287 & $\mathrm{p}=0.65$ & 427 & 1.081 & 3.93 & 1.172 & $\mathrm{p}=0.18$ \\
\hline ESR & 11.3 & 1.236 & 11.57 & 1.478 & $\mathrm{p}=0.43$ & 12 & 1.531 & 12.03 & 1.426 & $\mathrm{p}=0.87$ \\
\hline SR bilirubin & 0.58 & 0.0997 & 0.54 & 0.0702 & $p=0.18$ & 0.483 & 0.0986 & 0.46 & 0.077 & $\mathrm{p}=0.24$ \\
\hline Blood urea & 22.07 & 2.828 & 21.67 & 2.006 & $\mathrm{p}=0.44$ & 21.33 & 2.82 & 21.13 & 2.24 & $p=0.65$ \\
\hline SR Creatinine & 0.85 & 0.138 & 0.817 & 0.1621 & $p=0.25$ & 0.81 & 0.124 & 0.787 & 0.1629 & $\mathrm{p}=0.59$ \\
\hline SGOT & 19.77 & 2.208 & 20.1 & 1.117 & $\mathrm{p}=0.31$ & 19.63 & 2.059 & 20.4 & 1.734 & $\mathrm{p}=0.13$ \\
\hline SGPT & 23.77 & 1.675 & 23.73 & 1.53 & $\mathrm{p}=0.93$ & 23.7 & 1.8 & 23.4 & 1.61 & $\mathrm{p}=0.19$ \\
\hline
\end{tabular}

\section{DISCUSSION}

This randomized, prospective, open labelled comparative study evaluated the efficacy and tolerability of topical Tacrolimus over available topical Betamethasone in patients with Vitiligo.

Vitiligo is a clinical disease with progressive depigmentation of the skin affecting the psyche of the patient due to cosmetic reasons. As the pathology of the disease is varied the treatment available also varied which includes systemic steroids, phototherapy, surgical treatment and topical treatment. Though large numbers of treatment modalities are available, all are only palliative and affects patient's day to day life. Frequent visits to the hospital conflicts additional blow to the patient's morale and pocket.

Topical Tacrolimus an immunosuppressive drug which inhibits T-cell activation and production of various cytokines, which are the key factors in the pathogenesis of vitiligo, is a valuable alternative treatment to topical steroids. This study was conducted to assess the efficacy of topical Tacrolimus in Vitiligo by comparing with standard topical Betamethasone available in the study centre. Group-I-Control Group received $0.1 \%$ Betamethasone ointment. Group-II-Study Group received $0.1 \%$ Tacrolimus ointment.

Duration of the study was 8 weeks. The patients were evaluated at the end of every two weeks clinically for repigmentation and also for any side effects. The patients were evaluated before and after the study period for haematological and biochemical parameters for liver and renal functions. They were asked to come for follow up once in a month for six months and the same parameters were evaluated. Repigmentation is an important goal in the treatment of vitiligo. We assessed it by clinical evaluation, scoring techniques and by biopsies. Data was compiled and results statistically analysed.

In present study, there was no significant difference in the age, sex, duration and mean size of the lesion between the groups. the result of our study which included patients with lesions up to six months' duration well correlate with the results of the studies conducted by Travis et al and Lepe et al on patients with lesions meanduration-2-12 yrs and 2.2 yrs respectively. ${ }^{4}$

In present study, we have concentrated on the lesions in the face, neck and fore arm like Travis et al. Our study also shows better repigmentation in the face and neck. Studies conducted by Grimes et al, Tangeti et al and Lepe et al on lesions on various parts of the body have shown that better repigmentation with lesions on the face and neck. $^{4-6}$ This correlate well with the observations of our study.

Grimes et al have shown $88.33 \%$ repigmentation in a pilot study conducted for 8 weeks' duration in 6 patients. The same author has reported $89 \%$ repigmentation in another study conducted for 6 months with19 patients. ${ }^{5}$ This correlates with the observations of our study where we have observed $88 \%$ repigmentation.

Mean repigmentation in our study shows 30\% in Group-I and $59.17 \%$ in Group-II after 8 weeks of treatment and $51.67 \%$ and $88.33 \%$ after 6 months respectively. This 
shows Tacrolimus is more efficacious than Betamethasone. Travis et al observed repigmentation from the $3^{\text {rd }}$ week. ${ }^{7}$ In the present study repigmentation started from the $4^{\text {th }}$ week in Group-I and $2^{\text {nd }}$ week in Group-II. This shows Tacrolimus produces repigmentation much faster than Betamethasone. This study shows early onset of repigmentation.

Side effects like thinning of skin and transient burning sensation which subsided on its own were observed in Group-I and Group-II respectively, which is similar to the observation of Lepe et al. ${ }^{6}$ Thus, overall results of our study indicate that topical Tacrolimus produces repigmentation and is more efficacious than Betamethasone and does not produce any significant side effects. This study has limitations too. The sample size is small. Duration is also for 8 weeks only. So, the study needs to be done on a much larger and diverse population, for a longer period, also at the moment the drug is expensive.

\section{CONCLUSION}

In conclusion, this study shows that topical Tacrolimus as an alternate therapy to existing topical Betamethasone produces early response, significant repigmentation and lesser side effects. As Topical Tacrolimus can be applied at home, day to day life is not affected. As side effects are less it boosts up the psychological 1 morale of the patient. So, this could lead to better compliance and cure rate. In view of its efficacy and better tolerability it could be useful in the treatment of Vitiligo.

\section{ACKNOWLEDGMENTS}

Authors would like to acknowledge Cross Lands a division of Ranbaxy Pharmaceuticals for providing the drug $0.1 \%$ Tacrolimus Ointment.
Funding: No funding sources Conflict of interest: None declared

Ethical approval: The study was approved by the Institutional Ethics Committee

\section{REFERENCES}

1. Panuncio AL, Vignale R. Ultrastructural studies in stable vitiligo. Am J Dermatopathol. 2003;25(1):1620.

2. Seung-Kyung Hann, Mark G Lebwohl.Diseases of Pigmentation. Dermatol. 2005;4:1-10.

3. Simpson D, Noble S. Tacrolimus ointment- A Review of its use in Atopic Dermatitis and its clinical potential in other inflammatory skin conditions. Drugs. 2005;65(6):827-58.

4. Lepe V, Moncada B, Castanedo-Cazares JP, TorresAlvarez MB, Ortiz CA, Torres-Rubalcava AB. A double-blind randomized trial of $0.1 \%$ tacrolimus vs $0.05 \%$ clobetasol for the treatment of childhood vitiligo. Arch Dermato. 2003 May;139(5):581-5.

5. Grimes PE, Morriser. RNA expressions of proinflammatory cytokines. J Am Academy Dermatol. 2004;51:52-61.

6. Tangetti, EA. Tacrolimus ointment produces repigmentation in patients with vitiligo: Results of a prospective patients series. Cutis. 2003;71(2):158-62.

7. Lisa B, Travis BS, Weinberg JM, Nanette BS. Successful treatment of vitiligo with $0.1 \%$ Tacrolimus ointment. Arch Dermatol. 2003;139:5713 .

Cite this article as: Bai AS, Sujatha G, Preetha N. A prospective open label study of efficacy and tolerability of topical tacrolimus in Vitiligo. Int $\mathbf{J}$ Basic Clin Pharmacol 2017;6:1338-43. 